\title{
SELECTING INTERNATIONAL MARKET ENTRY STRATEGY IN A HOTEL INDUSTRY
}

\section{ВИБІР СТРАТЕГІЇ ВИХОДУ НА МІЖНАРОДНИЙ РИНОК В ГОТЕЛЬНІЙ ГАЛУЗІ \\ ВЫБОР СТРАТЕГИИ ВЫХОДА НА МЕЖДУНАРОДНЫЙ РЫНОК В ГОСТИНИЧНОЙ ОТРАСЛИ}

The article contains analysis of the process of forming the foreign market entry strategy, the factors that influence its development, and the systematization of strategic alternatives for entry strategy (indirect export, direct exports, licensing, joint ventures, ownership, direct investment). The complex of existing instruments of choosing the best strategic alternative for a particular company was researched. It was found out that the available tools are more suitable for manufacturing companies and do not take into account the specificity of services. In particular, such characteristics of services as intangibility and inability of their storage limit the use of strategic alternatives related to exporting. A possibility of adaptation the matrix for selection the strategy of entering the foreign market for service industries, especially for the hotel industry, was proposed. The application of the matrix for selection the entry strategy for a specific company from the UAE was illustrated.

Keywords: foreign market entry strategy, direct exporting, joint venture, licensing, direct investment, management by contract, strategic alternatives, the selection of foreign markets.

В статті досліджено прочес формування стратегї виходу на зарубіжний ринок та фактори, які впливають на ї̈ розроблення, систематизовано стратегічні альтернативи виходу на зарубіжний ринок (непрямий експорт, прямий експорт, ліџензування, спільне підприємництво, пряме інвестування). Проаналізовано інструментарій для вибору конкретним підприємством стратегічної альтернативи, яку доцільно застосувати для виходу на ринок конкретної країни. Виявлено, щчо наявні інструменти є більш придатними для виробничих компаній та не враховують спещифіку сфери послуг. Зокрема, такі особливості послуг, як їх невідчутність та незбережуваність, обмежують використання стратегічних альтернатив, пов'язаних з експортом. Запропоновано можливості адаптації матриці вибору стратегї виходу на зарубіжний ринок для сфери послуг, зокрема для готельної галузі. Проілюстровано можливості застосування матриці вибору стратегії виходу на зарубіжний ринок мережею готелів з Об'єднаних Арабських Еміратів.

Ключові слова: стратегія виходу на зарубіжний ринок, прямий експорт, спільне підприємство, ліцензування, пряме інвестування, управління за контрактом, стратегічні альтернативи, відбір зарубіжних ринків. 
В статье исследован процесс формирования стратегии выхода на зарубежный рынок и факторы, влияющие на ее разработку, систематизированы стратегические альтернативы выхода на зарубежный рынок (косвенный экспорт, прямой экспорт, лицензирование, совместное предпринимательство, прямое инвестирование). Проанализирован инструментарий для выбора конкретным предприятием стратегической альтернативы, которую целесообразно применить для выхода на рынок конкретной страны. Выявлено, что имеюшиеся инструменты являются более подходящими для производственных компаний и не учитывают специфику сферы услуг. $B$ частности, такие особенности услуг, как их неосязаемость и невозможность складирования, ограничивающие использование стратегий, связанных с экспортом. Предложены возможности адаптации матрищьы выбора стратегии выхода на зарубежный рынок для сферы услуг, в частности для гостиничной отрасли. Проиллюстрированы возможности применения матрицы выбора стратегии выхода на зарубежный рынок конкретной компанией из ОАЭ.

Ключевые слова: стратегия выхода на зарубежный рынок, прямой экспорт, совместное предприятие, лицензирование, прямое инвестирование, управление по контракту, стратегические альтернативы, отбор зарубежных рынков.

Introduction. In terms of globalization of markets and increased competition it is important for any company to develop an international marketing strategy. One of the important elements of international marketing strategy is the decision concerning the entry or penetration strategy into the foreign market. With so many alternatives for entering the international market, it can be difficult for a company to decide on the strategy that will meet its strategic objectives with the most success. This is why strategic planning is so important; different markets and industries will require a different approach. The research on entry strategies from a manufacturing perspective is extensive, but service industries have their own peculiarities, and therefore this research deals with the entry strategies from a service perspective.

Problem formulation. The topic of entry or penetration strategies has been discussed for decades by such researches as E. Anderson, G.Albaum, J.Strandskov, S.P. Douglas, A.M. Driscoll, F.R. Root, J.H. Dunning, and others [1, 2, 3, 4]. Since the middle of 1980 they have conducted research on entry strategies from a manufacturing perspective. J.H. Dunning proposes to group entry strategies to foreign markets on the basis of three alternatives [5]:

- production of goods or services in home country (export),

- production of goods or services in the foreign country by independent companies (licensing, franchising, contract manufacturing)

- production of goods or services in the foreign country by the company's own facilities (foreign direct investment and joint ventures).

At the end of the 1990 the researchers began to shift their focus from not just manufacturing but also a service perspective, the change of focus was a result of the increasing service sector. At the same time there are a lot of studies about the differences in the nature of services and products, which create special challenges for services marketers [6]. But there is lack of research that reveals the impact of 
particular services characteristics on the entry strategies for service companies. Entry mode research from a service perspective is still limited and need more studies for particular service industries.

The aim of this article is to gain better understanding of the selection of entry strategies from a service company perspective. Furthermore the research is limited to investigating the hotel industry and how they use entry mode when wanting to establish them on a new market.

Methodology. Theoretical and methodological basis of the study are the general scientific methods, such as comparative analysis and scientific generalizations. In addition, there were used special methods of market research (desk research and personal interviews) to collect empirical data on the possibilities of hotel company in a specific foreign market and the attractiveness of a selected country for entering its market.

Main results. To operate business in foreign countries, the primary consideration and most critical issue in international market entry strategy is the selection of appropriate entry mode. Entry mode selection is interpreted to mean an appropriate way for enterprises to enter foreign markets so as to operate their international businesses by exploiting their advantages [7].

There are many options for entering an overseas market - choosing the best one for a company depends on a number of factors, which may often contradict each other. Different entry strategies provide different levels of control, risk, profitability, and flexibility. For example, by selecting exporting strategies, the company will have the lowest risk, but also the low profit and the low level of control of marketing, strategy. And in case of choosing the investment strategy, profit and control can be much higher, but the risk increases significantly and the flexibility decreases. The choice will involve the level of control a company wants, and the resources it is able to commit, and it is often a compromise between different strategic alternatives.

Charles Hill in his research emphasizes that entry mode decision is influenced by three different variables; strategic variables, environmental variables, and transaction-specific variables [8]. The environmental variables include variables relating to country risk, location familiarity, demand, and competitive conditions that exist in the foreign market. The strategic variables are whether or not the firm shall adapt the product to the foreign market or if they can have the same product. Due to the similarities between the countries this variable is of less important at this time. The transactions specific variable stresses the importance of firm-specific advantages in know-how when explaining the competitive advantage. According to Johanson \& Vahlne [9] the decision on what entry mode to implement is due to companies' current state, companies past experiences, stability, access to resources, and structure of the target market. 
Another research provides the methodology of choosing the best entry strategy, based on two groups of factors [10].

The first group characterizes the attractiveness of host country market and includes: investment climate, tariff and non-tariff barriers for export, market growth, availability and cost of raw materials, labor costs and skills, the country's attitude to intellectual property rights protection, the country's attitude to environmental protection, membership in integration associations (like free trade zones, custom unions, and common markets), risks of doing business in the country.

The second group of factors determines the capacity of the enterprise: the size of the company, the experience in internationalization, the availability of financial resources, company image abroad, the uniqueness of the company's products, the stage of the product life cycle, capacity utilization, willingness of managers to risk, and the desire of managers to have complete control over the activities.

Practical decisions about choosing the best alternative of entry strategy should take into account all the above factors. In each case, some of them have a greater significance, while others are less important. Therefore, in practice, it is advisable to use a hierarchy of factors that meet the specifics of each industry and each company.

Method of selecting the strategic alternative for entering foreign markets involves the following steps:

1. Assess the importance of each factor for a particular company by expert assessments and assign weight.

2. Evaluate the score of each factor for a particular company by expert estimates.

3. Calculate the integral index for each of the two groups of factors (Index of attractiveness $I_{\text {attr }}$ and Index of capacities $I_{\text {cap }}$ ).

4. Place two integrated indexes at two axes of the matrix for selection the strategy of entering the foreign market (Fig. 1).

5. Select a strategic alternative that meets the calculated attractiveness index and index of capacities. Strategic alternative is a function that depends on variables $\mathrm{I}_{\text {attr }}$ and $\mathrm{I}_{\text {cap }}$ and takes discrete values. 


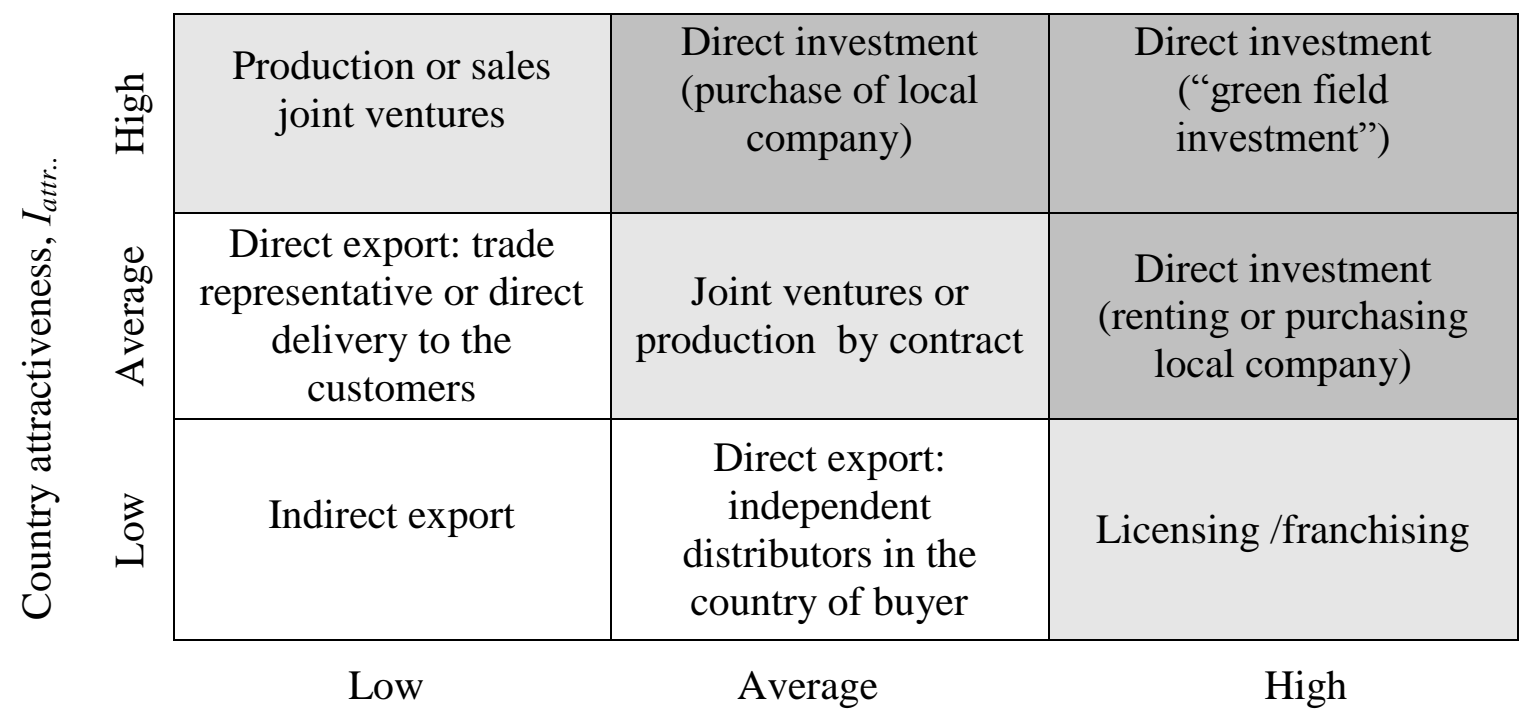

Enterprise capacities (possibilities), $I_{\text {cap. }}$

Fig. 1. Matrix for selection the strategy of entering the foreign market [11]:

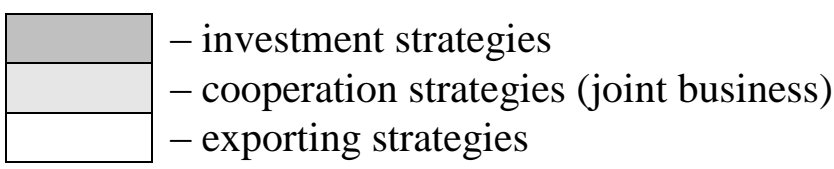

In this study, by extending traditional entry strategies, we limit our discussion on the hotel industry companies. Due to our focus on service firms, service characteristics are needed to be considered which may influence modification of the entry strategies. Researchers in the field of service marketing suggest to examine the unique characteristics of services: intangibility, perishability, heterogeneity, and inseparability [12]. Of particular importance to us are intangibility and perishability, because among the characteristics which differentiate services from products, they refer to the fact that (in general) services cannot be produced and stockpiled or stored before consumption: they exist only at the time of their production.

In hotel industry it is impossible to separate a service from its physical environment, including accommodation/building, location of the hotel, its environment etc. So there is a need to produce hotel services in the place of their consumption. Therefore, "pure" export strategies cannot be applied in hotel industry. As the term "export" means shipping the goods and services out of the port of a country. In international trade "export" refers to selling goods and services produced in the home country to other markets [13].

Theory of international service marketing gives us general idea about how the specifics of the service sector modify export strategy. Thus, the study of M. Erramilli examine the international activities of 175 U.S. service companies, from retailing, advertising, finance, software engineering, management consulting, 
architecture, and other industries. The study showed that the most frequently used method of entering the foreign markets for US services companies is to create a branch or subsidiary in a host country [14]. But in most cases that means that the company uses investing strategy with $100 \%$ ownership or joint venture.

In case of hotel industry export is possible only if the company does not export hotel services, but rather management services. This option is called "management by contract". In this case the company should have qualified managers, which can be used more profitably in the foreign market. Another possible option for a hotel chain to enter foreign market is to open an office (agency) in the host country, which will attract foreign clients in hotels that are located in home country or other countries. So, for hotel industry it's better to use terms "own agencies" and "management by contract" instead of "direct export", and "independent agencies" instead of "indirect export" (Fig. 2).

There is one more option for direct investment strategy in hotel industry "hub-and-spoke" approach. "Hub-and-spoke" is already very popular in air transportation and telecommunications [15]. In the hotel business it can be realized in the following way: the company is building in large megacity four or five stars hotels, and after some time open two or three stars hotels in neighboring less populous cities. "Hub" in this case may be not only the administrative capital of the country, but also a major commercial center.

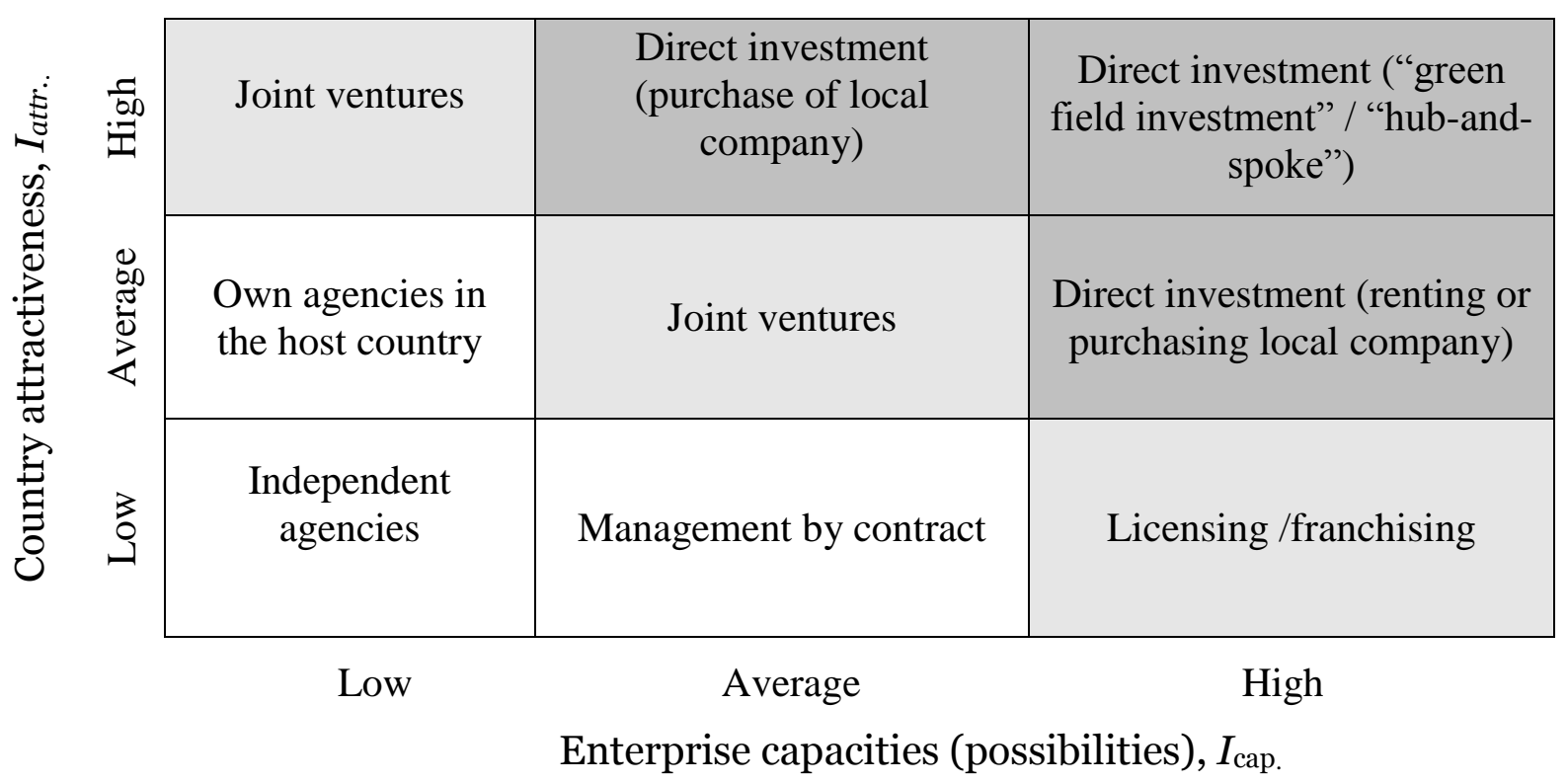

Fig. 2. Matrix for selection the strategy of entering the foreign market in hotel industry

To illustrate the application of the matrix for selection the strategy of entering the foreign market in hotel industry, we chose Jumeirah Group.

Jumeirah Group is a private company from United Arab Emirates that was founded in 1997 by Dubai government with the aim to become a hospitality industry leader through establishing a world class portfolio of luxury hotels and 
resorts. The Group is focusing in the luxury and unique hospitality industry, but is far from just another luxury hotel chain. Born in Dubai, it is considered a leader in imaginative and exhilarating experiences. Jumeirah Hotels, Resorts and Residences are regarded as among the most innovative in the world. Jumeirah Group portfolio includes hotels and resorts (Burj Al Arab, Jumeirah Emirates Towers, Jumeirah Beach Hotel, Madinat Jumeirah, Jumeirah Zabeel Saray in Dubai and Jumeirah and Etihad in Abu Dhabi), theme park (Wild Wadi Waterpark), spa brand Talise, Jumeirah Restaurants (the company's restaurant division) and The Emirates Academy of Hospitality Management and Jumeirah Hospitality [16].

They expand over 10 countries over the world. The unique idea that the Group uses in ten countries is not the same. Each hotel is carrying a new experience that showing the story of that place. Nevertheless, it stay luxurious and elegancy way of the Group strategy. They expand in Asia, southern, eastern and western of Europe. Global Hotels include Jumeirah Dhevanafushi and Jumeirah Vittaveli in Maldives, Jumeirah Himalayas Hotel in Shanghai, Jumeirah Frankfurt in Germany, Jumeirah Grand Hotel Via Veneto in Rome, Pera Palace Hotel Jumeirah in Istanbul, Jumeirah Bodrum Palace, Jumeirah Carlton Tower and Jumeirah Lowndes Hotel in London, Jumeirah Bilgah Beach Hotel in Azerbaijan, Jumeirah Messilah Beach Hotel \& Spa in Kuwait. Jumeirah currently has more than 20 hotels in its portfolio, including those it manages rather than owns - in markets such as Kuwait, China, Britain, and Italy. Jumeirah's expansion plans include projects currently under development in India, Jordan, Qatar, Thailand, Egypt, Morocco, Indonesia, and the Caribbean.

Jumeirah Group has signed a management agreement with IFG Basis Proect LLC to manage a luxury hotel on Nevsky Prospect in St. Petersburg, Russia. Due to delays with the reconstruction of the building and the impossibility of providing parking, the project is postponed. Moreover, Russia's economy is widely forecast to shrink this year because of the slide in oil prices and Western sanctions against Russia over the Ukraine crisis. The falling rouble and paying capacity of Russians is a challenge not only in terms of developing on Russian market, but also in terms of tourism to UAE (as Russia is among Emirates' top ten tourism source markets) [17].

In this regard, it would be advisable for Jumeirah Group to analyze the prospects of entering the markets of other northern European countries, for example, Sweden.

Based on interviews with industry experts and analyses of international countries indexes and rankings, we evaluated the attractiveness of the Swedish market for the company as the average, using the above mentioned methodology [10]. Although the number of factors demonstrate high attractiveness of Swedish market (low risks of doing business, high skilled labor, strong infrastructure, economic stability, low corruption level, high level of incomes and high standard of living), there are still several factors, which are not favorable enough: investment 
policy $\left(62^{\text {nd }}\right.$ place in the ranking of 140 countries in terms of effect of taxation on incentives to invest), high taxes $\left(112^{\text {nd }}\right.$ place in the ranking of 140 countries on total tax rate, that is $49,4 \%$ of profit, and $94^{\text {th }}$ place in term of effect of taxation on incentives to work), high costs of labor $\left(44^{\text {th }}\right.$ place in the ratio of pay and productivity, and $106^{\text {th }}$ place in hiring and firing practices), and such cultural barrier as the reluctance of luxury $[18,19,20]$.

The second group of factors, which determines the capacity of the enterprise is between high and average: Jumeirah Group has the availability of financial resources, good image abroad (especially in Asian countries and Southern Europe, in Sweden the company has not strong image yet), good experience in internationalization (but mostly in countries with a similar culture), and the uniqueness of the company's services.

According to the matrix of selection entry strategies, the most appropriate strategies for entering Jumeirah Group in the market of Sweden will be direct investment (renting or purchasing local company) or joint venturing with a local partner who has the experience and knowledge in terms of adaptation the concept and services to the peculiarities of Swedish market. The final choice of entry strategy is possible after more in-depth analysis of the market in terms of competition, consumers' behaviour, and availability of potential partners, as well as cost analysis of the proposed alternatives.

Conclusions. Decision concerning the entry strategy into the foreign market is one of the important elements of international marketing strategy. Service industries are different from manufacturing and need to have specific approach to formulating and choosing entry strategies. Such characteristics of services as intangibility and inability of their storage limit the use of strategic alternatives related to exporting. In this article we proposed a possibility of adaptation the matrix for selection the strategy of entering the foreign market for service industries, especially for the hotel industry. The application of the matrix for selection the entry strategy for Jumeirah Group from the UAE into the market of Sweden was illustrated. In further studies, it is advisable to analyze the impact of additional factors relating to market attractiveness and company capacity that are specific for hotel industry. Also promising research may concern the factors that determine the need to adapt hotel services to the market of a particular country.

\section{References:}

1. Albaum G., Strandskov J., Duerr E. and Dowd L. International Marketing and Export Management. - Addison-Wesley, Wokingham, 1989.

2. Anderson E. and Gatignon, H. Modes of foreign entry: a transaction cost analysis and propositions // Journal of International Business Studies. - 1986. - Vol. 17. - №3. - Pp. 1-26.

3. Douglas S.P. Evolution of global marketing strategy: scale, scope and synergy // Columbia Journal of World Business. - 1989. - Fall. - Pp. 47-59. 
4. Driscoll A.M., Paliwoda, S.J. Dimensionalizing international market entry mode choice // Journal of Marketing Management. - 1997. - Vol. 13. - №1-3. - Pp. 57-87.

5. Dunning J.H. Towards an eclectic theory of international production // Journal of International Business Studies. - 1980. - Spring/ Summer. - Pp. 9-31.

6. Zeithaml V. A., Parasuraman A., Berry L.L. Problems and Strategies in Services Marketing // Journal of Marketing. - 1985. - №49(Spring), 2. - Pp. 33-46.

7. Root F.R. Entry Strategies for International Markets. - San Francisco, CA: Lexington Books, 1994.

8. Hill C.W.L., Hwang P., Kim W.C. An eclectic theory of the choice of international entry mode // Strategic Management Journal. - 1990. - Vol. 11. - №2. - Pp. 117-128.

9. Johanson J, Vahlne J.-E. The Internationalization Process of the Firm - a Model of Knowledge Development and Increasing Foreign market Commitment? // Journal of International Business Study. - 1977. - Vol.8. - P.29.

10. Співаковська Т.В. Формування маркетингових стратегій машинобудівних підприємств в умовах інтернаціоналізації ринків : Дис... канд. екон. наук: 08.00.04 / Т.В. Співаковська - К.: НТУУ"КПІ", 2009.

11. Співаковська Т.В. Формування маркетингових стратегій машинобудівних підприємств в умовах інтернаціоналізації ринків : автореф. дис. канд. екон. наук: 08.00.04 / Т.В. Співаковська / Національний технічний університет України «КПІ». - К., 2009. - С.13.

12. Zeithaml V.A., Bitner M.J. Services Marketing: Integrating Customer Focus across the Firm. - NY: McGraw-Hill, 2000.

13. Joshi R.M. International Marketing. - New Delhi and New York: Oxford University Press, 2005.

14. Erramilli M.K. Entry mode choice in service industries // International marketing review. - 1990. - Vol.7. - №5.

15. Delve S. How the Hub-and-Spoke Model Transformed the Transportation Industry [Electronic resource]. - Retrieved from: http://www.inboundlogistics.com/cms/article/how-thehub-and-spoke-mode-transformed-the-transportation-industry.

16. About Jumeirah Group [Electronic resource]. - Retrieved from jumeirah.com: http://www.jumeirah.com/en/jumeirah-group/about-jumeirah-group.

17. Fewer Russians visit the UAE as rouble falls // Gulf News Tourism [Electronic resource]. - Retrieved from: http://gulfnews.com/business/sectors/tourism/fewer-russians-visitthe-uae-as-rouble-falls-1.1427839.

18. The Global Competitiveness Report 2015-2016 [Electronic resource]. - Retrieved from: http://reports.weforum.org/global-competitiveness-report-2015-2016/economies/\#economy=SWE

19. Doing Business Measuring Business Regulations. [Electronic resource]. - Retrieved from doingbusiness.org: http://www.doingbusiness.org/data/exploreeconomies/sweden/starting-abusiness.

20. Hofstede G. Cultural dimentions [Electronic resource]. - Retrieved from: http://geerthofstede.com/sweden.html. 